\title{
PEMBELAJARAN DALAM JARINGAN (DARING) DI MASA PANDEMI COVID-19 \\ SISWA MI MA'ARIF NU NGADIREJO KALIGESING PURWOREJO
}

\author{
Istinganah, S.Pd \\ MI Ma'arif NU Ngadirejo \\ Email: istinganah758@gmail.com \\ Siti Anisatun Nafi'ah, M.Pd \\ STAINU Purworejo \\ Email: anisnafiah14@gmail.com \\ Roikhatul Janah, M.Pd \\ STAINU Purworejo \\ Email: roikhatuljanah30@gmail.com
}

\begin{abstract}
The Online Learning During Pancemic Covid-19 At MI Ma'arif NU Ngadirejo Kaligesing Purworejo Central of Java, the research of study is (1) to describe the online learning during pandemic covid-19 at MI Ma'arif NU Ngadirejo Kaligesing Purworejo (2) the supporting and inhibiting factors of online learning during pandemic covid-19 at MI Ma'arif NU Ngadirejo Kaligesing Purworejo. This reseach employs qualitative approach, the data get by the observation, documentation, and interview. The subject of research is theachers, parents and students of MI Ma'arif $N U$ Ngadirejo Kaligesing. The analyze of data is triangulation of data with qualitative approach. The result of reseach is implementation online learning during pandemic at MI Ma'arif NU Ngadirejo Kaligesing Purworejo less effective because of several inhibiting factors, and not all of students have smartphones and the internet network is less stable.
\end{abstract}

Keywords: the online learning, MI Ma'arif NU Ngadirejo

\begin{abstract}
Abstrak
Pembelajaran Dalam Jaringan (Daring) Di Masa Pandemi Covid-19 siswa MI Ma'arif NU Ngadirejo Kaligesing Purworejo. Penelitian ini bertujuan untuk mengetahui (1) pembelajaran dalam jaringan (daring) di masa pandemi covid - 19 siswa MI Ma'arif NU Ngadirejo Kaligesing Purworejo (2) Faktor pendukung dan penghambat pembelajaran daring di masa pandemi covid-19 siswa MI Ma'arif Ngadirejo NU Kaligesing Purworejo. Metode penelitian yang digunakan adalah metode kualitatif deskriptif, teknik pengumpulan data menggunakan dokumentasi, observasi dan wawancara. Teknik analisis data menggunakan triangulasi data. Hasil dari penelitian ini adalah Pelaksanaan pembelajaran daring di MI Ma'arif NU
\end{abstract}


STAINU Purworejo: Jurnal As Sibyan

Jurnal Kajian Kritis Pendidikan Islam

Vol 4 No 1 Januari - Juni 2021

dan Manajemen Pendidikan Dasar

Homepage: https://ejournal.stainupwr.ac.id/

Email: sibyan.stainupwrj@gmail.com

E-ISSN: : 2599-2732

Ngadirejo yang kurang efektif karena beberapa faktor penghambat yaitu tidak semua siswa mempunyai smartphone dan kurang stabilnya jaringan internet.

\section{Kata Kunci: Pembelajaran dalam Jaringan, MI Ma'arif NU Ngadirejo.}

\section{A. PENDAHULUAN}

Indonesia saat ini sedang menghadapi situasi yang cukup sulit dengan merebaknya kasus virus covid-19 yang menyebar luas dengan sangat cepat. Virus COVID-19 dinyatakan sebagai pendemik oleh organisasi kesehatan dunia atau WHO. Menurut KBBI, pendemik adalah wabah yang berjangkit secara serempak di berbagai wilayah di seluruh dunia. Oleh karena itu, setiap orang, pemerintahan, dan negara di dunia harus saling bekerjasama menanggulangi dan mencegah penyebaran yang semakin meluas. Virus COVID-19 dapat berjangkit pada siapapun tidak memandang usia, jenis kelamin, dan asal negara. Setiap orang wajib untuk menjaga kebersihan diri dan menghindari kerumunan banyak orang untuk mencegah terpapar virus COVID-19.

Akibat dari wabah ini seluruh sekolah-sekolah ditutup untuk tidak menyelenggarakan pembelajaran secara langsung untuk mengurangi persebaran virus COVID-19. Untuk mencegah penyebaran Covid-19, Pemerintah daerah kabupaten Purworejo memberikan himbauan untuk menghentikan acara-acara yang dapat menyebabkan massa berkerumun. Maka dari itu, pembelajaran tatap muka yang mengumpulkan banyak siswa di dalam kelas ditinjau ulang pelaksanaanya.

Berdasarkan Surat Edaran Kemendikbud No 4 Tahun 2020 Tentang Pelaksanaan Kebijakan Pendidikan Dalam Masa Darurat Penyebaran Corona Virus Desease Covid-19 bahwa pembelajaran di sekolah dilaksanakan secara daring atau jarak jauh. Pembelajaran daring merupakan pembelajaran yang menggunakan jaringan internet dengan aksesibilitas, konektivitas, fleksibilitas, dan kemampuan untuk memunculkan berbagai jenis interaksi pembelajaran. ${ }^{1}$ Proses pembelajaran jarak jauh ini mengandalkan penggunaan teknologi sebagai sarana transfer ilmu

\footnotetext{
1 Ali Sadikin, Afreni Hamidah, Pembelajaran Daring di Tengah Wabah Covid-19, Jurnal Ilmiah Pendidikan Biologi Program Studi Pendidikan Biologi FKIP Universitas Jambi Volume 6, Nomor 02, Tahun 2020, Hal. 214-224
} 
STAINU Purworejo: Jurnal As Sibyan

Jurnal Kajian Kritis Pendidikan Islam

Vol 4 No 1 Januari - Juni 2021

dan Manajemen Pendidikan Dasar

Homepage: https://ejournal.stainupwr.ac.id/

Email: sibyan.stainupwrj@gmail.com

E-ISSN: : 2599-2732

atau virtual learning, berbagai aplikasi media pembelajaran harus dikuasai oleh para pendidik, peserta didik maupun orang tua yang harus mendampingi anak mereka dalam proses belajar mengajar. ${ }^{2}$

Keadaan pembelajaran daring yang menganjurkan menggunakan media elektronik seperti $h p$, laptop dan fasilitas internet belum bisa dirasakan oleh siswa dan siswi yang tinggal di daerah pedesaan, karena tidak semua wali murid mempunyai smart phone apalagi laptop, di tambah dengan tidak stabilnya jaringan internet membuat siswa, orang tua dan guru tidak bisa melaksanakan pembelajaran dengan proses pembelajaran daring secara maksimal dengan menggunakan teknologi.

Bagaimanapun juga pendidikan di tengah pandemi covid-19 harus tetap dilaksanakan. Karena pendidikan adalah suatu betuk investasi jangka panjang bagi seorang manusia. ${ }^{3}$ Maka dari itu solusi pembelajaran yang tepat perlu dilaksanakan ditengah jenuhnya siswa dalam menghadapi pandemi covid-19 yang tak kunjung reda. Siswa kelas dasar masih sangat membutuhkan pendampingan secara penuh, tetapi terkadang orang tua siswa tidak mengetahui tentang materi yang di ajarkan atau terkadang orang tua siswa terlalu sibuk bekerja sehingga tidak bisa menemani anak belajar. Akhirnya keadaan anak yang sudah jenuh dengan motif belajar seperti ini, membuat mereka menuangkan perasaannya dengan menggunakan waktu mereka untuk bermain ketika tidak ada yang mendampingi belajar.

Hasil observasi peneliti di MI Ma'arif NU Ngadirejo menemukan fenomena pembelajaran daring di tengah pandemi covid yang dilaksanakan secara tatap muka terbatas di salah satu rumah wali murid karena terbatasnya akses internet dan minimnya fasilitas smartphone serta ketidakmampuan sebagian orang tua siswa dalam mendampingi belajar karena sibuk bekerja.

Dari uraian diatas peneliti tertarik melakukan penelitian yang terkait dengan bagaimana pembelajaran daring dimasa pandemi covid-19 siswa MI Ma'arif NU

\footnotetext{
${ }^{2}$ Sri Gusty, Nurmiati dkk, Belajar Mandiri Pembelajaran Daring di Tengah Pandemi Covid-19, ( Jakarta : Yayasan Kita Menulis, 2020), hlm 16

${ }^{3}$ Siti Suprihatin, Upaya Guru Dalam Meningkatkan Motivasi Belajar Siswa, Pendidikan Ekonomi FKIP Universitas Muhammadiyah Metro, Vol.3.No.1 (2015) 73-82
} 
STAINU Purworejo: Jurnal As Sibyan

Jurnal Kajian Kritis Pendidikan Islam

Vol 4 No 1 Januari - Juni 2021

dan Manajemen Pendidikan Dasar

Homepage: https://ejournal.stainupwr.ac.id/

Email: sibyan.stainupwrj@gmail.com

E-ISSN: : 2599-2732

Ngadirejo Kaligesing Purworejo, sehingga penelitian ini berjudul "Pembelajaran

Dalam Jaringan (Daring) Di Masa Pandemi Covid-19 Siswa MI Ma'arif NU

Ngadirejo Kaligesing Purworejo".

Berdasarkan uraian latar belakang di atas, maka yang menjadi rumusan masalah dalam penelitian ini adalah : (1) Bagaimana pembelajaran dalam jaringan (daring) di masa pandemi covid-19 siswa MI Ma'arif NU Ngadirejo Kaligesing Purworejo?. (2) Bagaimana faktor pendukung dan faktor penghambat pembelajaran dalam jaringan (daring) di masa pandemi covid-19 siswa MI Ma'arif Ngadirejo NU Kaligesing Purworejo?

\section{B. METODOLOGI}

Penelitian ini menggunakan jenis penelitian kualitatif. Tempat penelitian utama adalah di MI Ma'arif NU Ngadirejo, dan untuk melengkapi data observasi juga dilaksanakan di rumah beberapa siswa yang dipilih secara acak dari kelas I - VI beserta wali murid dari siswa tersebut. Waktu penelitian selama dua bulan, dimulai dengan observasi di MI Ma'arif NU Ngadirejo dan bertemu dengan salah satu guru yang sedang piket di MI Ma'arif NU Ngadirejo.

Adapun subjek penelitian dalam tulisan ini adalah siswa-siswi, guru dan orang tua siswa dan siswi MI Ma'arif NU Ngadirejo Kecamatan Kaligesing Kabupaten Purworejo. Objek penelitian adalah pembelajaran daring di MI Ma'arif NU Ngadirejo Kaligesing purworejo. Teknik pengumpulan data menggunakan dokumentasi, observasi dan wawancara. Teknik analisis data menggunakan reduksi data, penyajian data dan verifikasi data. Adapun keabsahan data menggunakan teknik triangulasi data.

\section{HASIL DAN PEMBAHASAN}

Pembelajaran dalam jaringan (daring) di MI Ma'arif NU Ngadirejo pada masa pandemi COVID-19 tetap dilaksanakan walaupun masih jauh dari sempurna. Sebagaimana diungkapkan oleh Kepala Madrasah Ibtidaiyah Ma'arif NU Ngadirejo bahwa pembelajaran daring yang seharusnya sepenuhnya berbasis internet hanya 
STAINU Purworejo: Jurnal As Sibyan

Jurnal Kajian Kritis Pendidikan Islam

Vol 4 No 1 Januari - Juni 2021

dan Manajemen Pendidikan Dasar

Homepage: https://ejournal.stainupwr.ac.id/

Email: sibyan.stainupwrj@gmail.com

E-ISSN: : 2599-2732

bisa dilaksanakan oleh sebagian siswa saja, karena tidak semua siswa/orang tua siswa mempunyai smartphone. Ada sebagian kecil siswa yang belajar pada masa pandemi secara mandiri dengan arahan dari guru setiap satu minggu sekali. ${ }^{4}$

Hal ini dikuatkan oleh guru kelas III MI Ma'arif NU Ngadirejo yang mengatakan bahwa pembelajaran daring di MI Ma'arif NU Ngadirejo sebenarnya berjalan dengan baik jika saja didukung oleh jaringan internet yang stabil dan SDM orang tua yang baik. Keadaan orang tua dengan latar belakang ekonomi yang berbeda-beda juga mempengaruhi pelaksanaan pembelajaran daring yang sedang dilaksanakan.

Tahapan pembelajaran daring yang pertama seperti dikemukakan oleh guru tersebut yaitu dengan membuat grup Whats App. Melalui grup tersebut antara guru, siswa dan juga orang tua berinteraksi dalam pembelajaran. Karena wilayah MI Ma'arif NU Ngadirejo berada di pegunungan belajar daring paling maksimal dengan menggunakan aplikasi WA.

Dalam satu kelas tidak semua siswa / orang tua siswa mempunyai smartphone yang bisa digunakan untuk pembelajaran daring, maka menurut guru tersebut berinisiatif dengan membuat kelompok kecil untuk belajar bersama dan berkonsultasi dengan guru tentang materi pelajaran dan tugas setiap satu minggu sekali. Hal ini untuk mengurangi kegiatan berkerumun dalam keadaan pandemi covid-19.5

Berbeda dengan pendapat guru kelas V MI Ma'arif NU Ngadirejo yang mengatakan bahwa pembelajaran daring di kelas V MI Ma'arif NU Ngadirejo sangat tidak efektif, karena minimnya interaksi antara guru dengan siswa dan pembelajaran sangat bersifat teoristis dan minim praktek. Hal ini karena di kelas $\mathrm{V}$ MI ma'ari NU Ngadirejo hanya sebagian kecil siswa/wali siswa yang mempunyai smartphone.

\footnotetext{
${ }^{4}$ Wawancara dengan Kepala Madrasah Ibtidaiyah Ma'arif NU Ngadirejo pada tangggal 25 November 2020.

${ }^{5}$ Wawancara dengan guru kelas III MI Ma'arif NU Ngadirejo pada tanggal 25 November 2020
} 
STAINU Purworejo: Jurnal As Sibyan

Jurnal Kajian Kritis Pendidikan Islam

Vol 4 No 1 Januari - Juni 2021

dan Manajemen Pendidikan Dasar

Homepage: https://ejournal.stainupwr.ac.id/

Email: sibyan.stainupwrj@gmail.com

E-ISSN: : 2599-2732

Jadi pembelajaran daring di kelas $\mathrm{V}$ hanya dilakukan oleh siswa yang mempunyai smartphone yang tergabung dalam grup WA. Untuk mengatasi kesulitan bagi siswa / wali siswa yang tidak mempunyai smartphone, guru memberikan waktu untuk konsultasi setiap satu minggu sekali. Dalam berkonsultasi siswa bisa bertanya tentang kesulitan materi pelajaran juga untuk mengumpulkan tugas selama pembelajaran di rumah.6

Hal ini senada dengan beberapa orang tua siswa yang mengatakan bahwa pembelajaran daring di MI Ma'arif NU Ngadirejo kurang efektif karena tidak semua orang tua siswa mempunyai smartphone. Dan juga pendampingan orang tua terhadap anak dalam waktu belajar yang kurang maksimal karena kesibukan orang tua dalam bekarja mencari nafkah juga dalam menyelesaikan pekerjaan rumah tangga. Menurut sebagian orang tua pembelajaran daring untuk tingkat SD / MI masih sangat memerlukan pendampingan orang tua, karena pembelajaran daring dilaksanakan dengan aplikasi WA yang sangat minim untuk pemahaman siswa tentang materi pembelajaran. Sebagian orang tua juga mengatakan dalam mendampingi putra-putri mereka terkadang kesulitan dengan materi pelajaran yang tidak dimengerti oleh mereka. Bahkan mereka merasa bahwa pembelajaran daring memberatkan orang tua, karena mereka harus menyediakan kuota internet setiap saat untuk proses pembelajaran daring. Sebagian orang tua juga mengatakan pembelajaran daring memberatkan orang tua yang tidak mempunyai smartphone, karena mereka harus lebih meluangkan waktu mendampingi putra-putri mereka belajar.7

Dalam hal pembelajaran daring sebagian siswa mengungkapkan bahwa dalam tahapannya ada yang menyenangkan dan ada juga yang merasa kesulitan. Sebagian siswa yang merasa senang dengan pembelajaran daring karena mereka paham dengan materi dan juga merasa bahwa pembelajaran daring mempunyai banyak waktu luang di rumah bersama dengan keluarga. Sedangkan sebagian siswa yang

\footnotetext{
${ }^{6}$ Wawancara dengan guru kelas V MI Ma'arif NU Ngadirejo pada tanggal 24 November 2020

${ }^{7}$ Wawancara dengan orang tua siswa MI Ma'arif NU Ngadirejo pada tanggal 25 November 2020
} 
STAINU Purworejo: Jurnal As Sibyan

Jurnal Kajian Kritis Pendidikan Islam

Vol 4 No 1 Januari - Juni 2021

dan Manajemen Pendidikan Dasar

Homepage: https://ejournal.stainupwr.ac.id/

Email: sibyan.stainupwrj@gmail.com

E-ISSN: : 2599-2732

merasa kesulitan dengan tahapan pembelajaran daring karena mereka yang tidak punya fasilitas smartphone dan juga yang belum paham dengan materi yang dipelajari.8

Dari beberapa pendapat di atas dapat dijelaskan bahwa pembelajaran daring di MI Ma'arif NU Ngadirejo dilaksanakan dengan menggunakan aplikasi WA sebagai media interaksi belajar antara guru, siswa bahkan orang tua siswa yang mempunyai smartphone. Bagi siswa yang tidak mempunyai smartphone melaksanakan pembelajaran mandiri di rumah dengan dampingan orang tua dan berkonsultasi dengan guru satu minggu sekali untuk mendapatkan dan mengumpulkan tugas.

Pelaksanaan pembelajaran daring di MI Ma'aarif NU Ngadirejo sebagaimana dijelaskan oleh guru MI Ma'arif NU Ngadirejo dengan menggunakan aplikasi WA sebagai media berinteraksi antara guru, siswa dan orang tua siswa. Melalui aplikasi tersebut guru melaksanakan proses pembelajaran dengan mengirim materi yang harus dipelajari dan tugas yang harus dikerjakan oleh siswa. Tugas tersebut kemudian dikirimkan melalui aplikasi WA untuk dievaluasi oleh guru. Jika siswa merasa kurang paham dengan materi yang dipelajari, siswa bisa meminta penjelasan guru terkait dengan materi melalui aplikasi WA tersebut. Sedangkan bagi siswa / orang tua yang tidak mempunyai smartphone berkonsultasi dengan guru tentang materi yang belum dipahami satu minggu sekali di sekolah dan mengumpulkan tugas yang sudah dikerjakan.9

Menurut guru MI M'arif NU Ngadirejo bahwa dengan belajar daring menjadikan orang tua lebih dekat dengan anak, dan sekaligus merasakan bagaimana susah dan sulitnya membimbing putra-putri dalam belajar sebagaimana yang dirasakan guru ketika membimbing siswa-siswi di sekolah.10

Hal ini juga diungkapkan oleh sebagian orang tua siswa bahwa mereka juga mendampingi pembelajaran karena sebagian siswa belum terampil dalam mengoperasikan smaertphone bagi siswa yang masih di kelas rendah, terutama

\footnotetext{
${ }^{8}$ Wawancara dengan siswa MI Ma'arif NU Ngadirejo pada tanggal 25 November 2020

${ }^{9}$ Wawancara dengan guru kelas III MI Ma'arif NU Ngadirejo pada tanggal 25 November 2020

${ }^{10}$ Wawancara dengan guru kelas II MI Ma'arif NU Ngadirejo pada tanggal 25 November 2020
} 
untuk belajar dengan aplikasi WA. Sedangkan bagi siswa kelas tinggi rata-rata sudah bisa belajar dengan aplikasi WA dan sebagian orang tua hanya mengawasi saat proses belajar daring.

Tidak demikian yang terjadi dengan siswa yang tidak mempunyai smartphone, orang tua siswa kelas rendah lebih banyak waktu untuk mendampingi belajar karena terkadang kondisi demikian membuat bosan siswa untuk belajar daring. Sedangkan siswa kelas tinggi orang tua hanya cukup mengawasi disela-sela mngerjakan pekerjaan rumah tangga.11

Evaluasi pembelajaran daring dilaksanakan setiap selesai mempelajari materi pelajaran. Hal ini seperti diungkapkan oleh guru MI Ma'arif NU Ngadirejo bahwa evaluasi pembelajaran dilaksanakan untuk mengetahui sejauh mana siswa memahami materi yang telah di ajarkan. Setelah evaluasi selesai dikerjakan maka di konsultasikan dengan guru melalui aplikasi WA dan bagi siswa yang tidak mempunyai aplikasi WA maka siswa mengumpulkan hasil evaluasi setiap satu minggu sekali. Guru MI Ma'arif NU Ngadirejo mengatakan bahwa kebanyakan hasil evaluasi siswa bernilai bagus karena salah satu faktornya adalah pendampingan orang tua saat belajar daring di rumah.12

Sebagaimana diceritakan oleh sebagian siswa MI Ma'arif NU Ngadirejo bahwa mereka senang dalam pembelajaran daring karena mereka tidak harus bangun pagi dan mandi pagi untuk segera pergi ke sekolah. Mereka juga mengatakan bahwa mereka mempunyai banyak waktu luang di rumah bersama dengan keluarga dan waktu untuk bermain. Mereka mengkondisikan waktu untuk belajar dan bermain selama dalam proses pembelajaran daring di rumah.

Sebagian dari siswa juga berkeluh kesah tentang pembelajaran daring dalam hal kesulitan memahami materi pelajaran terutama pelajaran matematika, yang menurut mereka lebih menyenangkan dan paham bila belajar bersama guru di kelas. Bagi siswa kelas rendah merasa kesulitan ketika mereka harus belajar

\footnotetext{
${ }^{11}$ Wawancara dengan orang tua siswa MI Ma'arif NU Ngadirejo pada tanggal 25 November 2020

${ }^{12}$ Wawancara dengan guru kelas III MI Ma'arif NU Ngadirejo pada tanggal 25 November 2020
} 
STAINU Purworejo: Jurnal As Sibyan

Jurnal Kajian Kritis Pendidikan Islam

Vol 4 No 1 Januari - Juni 2021

dan Manajemen Pendidikan Dasar

Homepage: https://ejournal.stainupwr.ac.id/

Email: sibyan.stainupwrj@gmail.com

E-ISSN: : 2599-2732

menggunakan aplikasi WA yang terkadang harus dibantu dan didampingi oleh orang tua mereka.13

Dalam hal pembelajaran daring otrang tua siswa mengatakan bahwa mereka merasa kesulitan dalam hal pendampingan belajar yang harus meluangkan waktu lebih dalam setiap harinya. Mereka juga mengatakan dalam mendampingi putraputri mereka belajar kurang paham dengan materi pelajaran yang dipelajari putraputri mereka. Sehingga mereka harus selalu berkonsultasi dengan guru tentang materi yang belum dipahami putra-putri mereka dengan aplikasi WA dalam grup masing-masing kelas.

Sebagian orang tua juga mengatakan bahwa mereka juga merasa bahwa pembelajaran daring memberatkan karena harus tersedia kuota internet dalam setiap harinya guna kepentingan putra-putri mereka belajar. Dalam hal ini orang tua juga mengeluhkan biaya pembelian kuota internet yang terkadang tidak selalu ada dan tersedia. 14

1. Faktor pendukung pembelajaran daring di MI Ma'arif NU Ngadirejo

Faktor pendukung pembelajaran daring di MI Ma'arif NU Ngadirejo sebagaimana diungkapkan oleh kepala MI Ma'arif NU Ngadirejo yang paling utama adalah smartphone, yang harus dimilki oleh siswa / orang tua siswa dalam belajar daring. Karena dengan samrtphone tersebut kegiatan belajar mengajar dilaksanakan dengan membuat grup belajar di aplikasi WA. Selain smartphone yang harus ada juga harus tersedia kuota internet untuk aplikasi WA agar bisa terlaksana proses pembelajaran. Selain itu juga jaringan internet yang stabil untuk bisa terhubung dengan grup WA tersebut. Dijelaskan oleh kepala MI Ma'arif NU Ngadirejo jejaring internet yang bisa digunakan untuk belajar daring di MI Ma'arif NU Ngadirejo adalah WA.

Selain itu faktor pendukung pembelajaran daring yaitu tersedianya buku paket dan LKS sebagai sumber belajar dan sarana berlatih untuk pemahaman materi

\footnotetext{
${ }^{13}$ Wawancara dengan siswa MI Ma'arif NU Ngadirejo pada tanggal 25 November 2020

${ }^{14}$ Wawancara dengan orang tua siswa MI Ma'arif NU Ngadirejo pada tanggal 26 November 2020
} 
STAINU Purworejo: Jurnal As Sibyan

Jurnal Kajian Kritis Pendidikan Islam

Vol 4 No 1 Januari - Juni 2021

dan Manajemen Pendidikan Dasar

Homepage: https://ejournal.stainupwr.ac.id/

Email: sibyan.stainupwrj@gmail.com

E-ISSN: : 2599-2732

pelajaran. Hal yang lain yaitu pendampingan orang tua dalam belajar daring untuk membantu putra-putri mereka mengopersikan smartphone bagi siswa kelas rendah. 15

Hal ini senada dengan penjelasan guru MI Ma'arif NU Ngadirejo bahwa faktor pendukung terlaksananya pembelajaran daring adalah smartphone bagi siswa/orang tua siswa yang mempunyai, akses internet yang stabil juga kuota internet yang harus selalu tersedia untuk proses pembelajaran. Selain itu kreatifitas guru dalam pembelajaran juga diperlukan agar siswa yang tidak mudah jenuh dan bosan selama belajar daring. 16

Menurut orang tua siswa pendukung utama pembelajaran daring adalah smartphone, jaringan internet yang stabil juga tersedianya kuota internet. Selain itu ada buku paket sebagai sumber belajar dalam pembelajaran daring. Adanya biaya pembelian kuota juga termasuk salah satu pendukung dalam pembelajaran daring agar smartphone selalu terhubung dengan jaringan internet bila kuota selalu ada pada smartphone mereka.17

Sedangkan menurut pendapat beberapa siswa pendukung dalam pembelajaran daring selain yang sudah dijelaskan di atas adalah pendampingan orang tua dalam belajar daring karena tidak semua siswa bisa mengoperasikan aplikasi WA untuk belajar daring. Selain itu orang tua juga menjadi tempat bertanya bagi mereka ketika dalam belajar daring di rumah ketika mereka kesulitan dalam memahami materi pelajaran sebelum mereka berkonsultasi dengan guru melalui aplikasi WA.

Dari beberapa pendapat di atas dapat ketahui bahwa faktor pendukung dari pelaksanaan pembelajaran daring di MI Ma'arif NU Ngadirejo adalah adanya smartphone yang disediakan oleh orang tua siswa untuk putra-putri mereka melaksanakan pembelajaran, ketersediaan kuota dan jaringan internet yang stabil agar selalu dapat berhubungan atau berinteraksi antara guru, siswa dan juga orang

15 Wawancara dengan Kepala Madrasah Ibtidaiyah Ma'arif NU Ngadirejo pada tangggal 25 November 2020.

${ }^{16}$ Wawancara dengan guru kelas V siswa MI Ma'arif NU Ngadirejo pada tanggal 25 November 2020

17 Wawancara dengan orang tua siswa MI Ma'arif NU Ngadirejo pada tanggal 26 November 2020 
STAINU Purworejo: Jurnal As Sibyan

Jurnal Kajian Kritis Pendidikan Islam

Vol 4 No 1 Januari - Juni 2021

dan Manajemen Pendidikan Dasar

Homepage: https://ejournal.stainupwr.ac.id/

Email: sibyan.stainupwrj@gmail.com

E-ISSN: : 2599-2732

tua siswa melalui aplikasi WA dalam grup belajar. Faktor pendukung lainnya adalah buku paket sebagai sumber belajar juga waktu luang orang tua untuk mendampingi putra-putri mereka belajar daring.

2. Faktor penghambat pembelajaran daring di MI ma'arif NU Ngadirejo

Faktor penghambat pembelajaran daring di MI Ma'arif NU Ngadirejo sebagaimana dijelaskan oleh Kepala MI Ma'arif NU Ngadirejo yang terutama yaitu tidak semua siswa/orang tua siswa mempunyai smartphone untuk melaksanakan pembelajaran daring. Karena faktor ekonomi orang tua siswa yang sebagian besar bekerja sebagai petani dan buruh harian lepas membuat mereka belum memprioritaskan adanya smartphone sebagai salah satu fasilitas kehidupan di keluarga mereka. 18

Hal ini senada dengan yang dikatakan guru MI Ma'arif NU Ngadirejo bahwa SDM orang tua juga menjadi salah satu penghambat proses pembelajaran daring. Karena SDM ini juga menjadi salah satu faktor baik / buruknya keadaan ekonomi di keluarga orang tua siswa. Menurut guru MI Ma'arif NU Ngadirejo selain itu juga tersedianya kuota internet atau biaya pembelian kuota internet juga menjadi salah satu penghambat pembelajaran daring.19

Sedangkan orang tua siswa mengatakan selain faktor penghambat di atas juga mereka harus meluangkan lebih banyak waktu untuk mendampingi putra-putri mereka, sedangkan sebagian besar dari mereka sibuk bekerja untuk memenuhi kebutuhan keluarga. Selain itu siswa / orang tua siswa yang tidak mempunyai smartphone harus benar-benar lebih meluangkan waktu lebih banyak untuk mendampingi putra-putri mereka balajar di rumah. Orang tua juga harus menyediakan kuota / biaya pembelian kuota lebih banyak, untuk kepentingan belajar daring lebih dari hari-hari biasanya. 20

18 Wawancara dengan Kepala Madrasah Ibtidaiyah Ma'arif NU Ngadirejo pada tangggal 25 November 2020.

${ }^{19}$ Wawancara dengan guru kelas V siswa MI Ma'arif NU Ngadirejo pada tanggal 25 November 2020

${ }^{20}$ Wawancara dengan orang tua siswa MI Ma'arif NU Ngadirejo pada tanggal 26 November 2020 
Sebagian siswa-siswi MI Ma'arif NU Ngadirejo mengatakan bahwa penghambat pembelajaran daring bagi mereka adalah kurangnya interaksi dengan guru, sehingga mereka merasa kesulitan untuk memahami materi pembelajaran terutama untuk pelajaran matematika dan lebih sulit lagi bagi siswa-siswi MI Ma'arif NU Ngadirejo di kelas atas. Mereka harus lebih ekstra belajar karena pemahaman materi harus mereka capai dengan kurangnya interaksi antara guru dengan siswa.

Dari beberapa pendapat di atas dapat diketahui bahwa pembelajaran dalam jaringan (daring) di MI Ma'arif NU Ngadirejo Kaligesing Pirworejo tidak efektif karena tidak semua siswa mempunyai $\mathrm{Hp}$ android/Smartphone sebagai media elektronik alat penunjang utama pelaksanaan pembelajaran daring. Penilaian pembelajaran daring di MI Ma'araif NU Ngadirejo juga tidak efektif karena bukan kemampuan siswa secara murni dalam mengerjakan evaluasi, tetapi juga dibantu oleh orang tua siswa.

Dari penjelasan di atas juga dapat diketahui bahwa faktor pendukung pembelajaran dalam jaringan (daring) di MI Ma'arif NU Ngadirejo bagi siswa adalah buku paket sebagai sumber belajar, pemantauan/pendampingan guru dalam proses pembelajaran melalui aplikasi WA. Sedangkan faktor penghambat pembelajaran dalam jaringan (daring) di MI Ma'arif NU Ngadirejo bagi siswa tidak tersedianya smartphone, tidak adanya kuota internet dan biaya untuk pembelian kuota internet, tidak ada jaringan internet dan kurangnya waktu luang orang tua dalam mendampingi putra-putri mereka belajar daring.

\section{KESIMPULAN}

Setelah penulis mengadakan penelitian dan menganalisis data demi data yang diperoleh dalam rangka pembahasan skripsi yang berjudul "Pembelajaran Dalam Jaringan (Daring) Di Masa Pandemi Covid-19 Siswa MI Ma'arif NU Ngadirejo Kaligesing Purworejo" maka secara garis besar dapat disimpulkan:

1. Pembelajaran dalam jaringan (daring) di MI Ma'arif NU Ngadirejo Kaligesing Pirworejo tidak efektif karena tidak semua siswa mempunyai $H p$ 
STAINU Purworejo: Jurnal As Sibyan

Jurnal Kajian Kritis Pendidikan Islam

Vol 4 No 1 Januari - Juni 2021

dan Manajemen Pendidikan Dasar

Homepage: https://ejournal.stainupwr.ac.id/

Email: sibyan.stainupwrj@gmail.com

E-ISSN: : 2599-2732

android/Smartphone sebagai media elektronik alat penunjang utama pelaksanaan pembelajaran daring. Penilaian pembelajaran daring di MI Ma'araif NU Ngadirejo juga tidak efektif karena bukan kemampuan siswa secara murni dalam mengerjakan evaluasi, tetapi juga dibantu oleh orang tua siswa.

2. Faktor pendukung pembelajaran dalam jaringan (daring) di MI Ma'arif NU Ngadirejo bagi siswa adalah buku paket sebagai sumber belajar, pemantauan/pendampingan guru dalam proses pembelajaran melalui aplikasi WA. Sedangkan faktor penghambat pembelajaran dalam jaringan (daring) di MI Ma'arif NU Ngadirejo bagi siswa tidak tersedianya smartphone bagi setiap siswa, tidak adanya kuota internet dan biaya untuk pembelian kuota internet, jaringan internet yang kurang stabil dan kurangnya waktu luang orang tua dalam mendampingi putra-putri mereka belajar daring.

SDM orang tua juga menjadi penghambat dalam pelaksanaan pembelajaran dalam jaringan (daring) di tingkat SD/MI, karena usia anak SD/MI masih sangat membutuhkan pendampingan orang tua dalam belajar daring dalam mengoperasikan smartphone juga dalam pengunaan aplikasi WA untuk interaksi antara guru dengan murid dalam pembelajaran.

\section{DAFTAR PUSTAKA}

Achmad Jayul, Edi Irwanto, 2020 "Model Pembelajaran Daring Sebagai Alternatif Proses Kegiatan Belajar Pendidikan Jasmani di Tengah Pandemi Covid-19, Jurnal Prodi Pendidikan Jasmani Kesehatan dan Rekreasi, Universitas PGRI Banyuwangi, Vol. 6, No. 2, Hal. 190 - 199, Juni 2020

Ali Sadikin, Afreni Hamidah, 2020 "Pembelajaran Daring di Tengah Wabah Covid-19", Jurnal Ilmiah Pendidikan Biologi Program Studi Pendidikan Biologi FKIP Universitas Jambi Volume 6, Nomor 02, Tahun 2020, Hal. 214224

Cecep Kustandi, Daddy Darmawan "Pengembangan Media Pembelajaran", Jakarta : Kencana,

Meda Yuliani dkk, 2020 “Pembelajaran Daring Untuk Pendidikan : Teori dan penerapan”, Jakarta : Yayasan Kita Menulis 
STAINU Purworejo: Jurnal As Sibyan Jurnal Kajian Kritis Pendidikan Islam

\section{dan Manajemen Pendidikan Dasar}

Homepage: https://ejournal.stainupwr.ac.id/

Email: sibyan.stainupwrj@gmail.com

E-ISSN: : 2599-2732

Siti Suprihatin, 2015 “Upaya Guru Dalam Meningkatkan Motivasi Belajar Siswa', Jurnal Pendidikan Ekonomi FKIP Universitas Muhammadiyah Metro, Vol.3.No.1 (2015) 73-82

Sri Gusty, Nurmiati dkk, 2020 "Belajar Mandiri Pembelajaran Daring di Tengah Pandemi Covid-19”, Jakarta : Yayasan Kita Menulis

Yusuf Bil Faqih, M Nur Qomarudin, 2020 "Esensi Pengembangan Pembelajaran Daring", Yogyakarta : Deepublish 